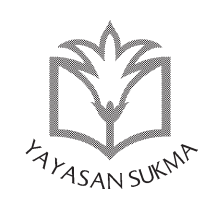

SUKMA: JURNAL PENDIDIKAN

ISSN: 2548-5105

Volume 1 Issue 1, Jan-Jun 2017, hlm. 19-55

\title{
THINK FUTURE, ACT PRESENT Looking Beyond the Closed Door
}

\author{
Evy I. Siregar; Nadiya A. Hayati; Nurul Fadila; \\ Agung Pratama; Yusuf H. Yudha \\ Sekolah Sukma Bangsa Aceh, Indonesia \\ email: evy.siregar@gmail.com
}

\section{Abstrak}

Tulisan ini mencoba menggambarkan bagaimana persepsi kondisi pendidikan kita saat ini, dan usulan untuk mengatasinya berdasarkan pengalaman. Diawali dengan gambaran kondisi pendidikan yand dideskripsikan melalui alat ukur pendidikan yang digunakan sebagian besar negara-negara di dunia, ditawarkan cara yang telah dicoba diterapkan melalui beberapa mata ajaran terutama di bidang sains dan bahasa. Cara ini dilakukan dengan usaha menyelaraskan kurikulum, proses belajar-mengajar serta alatukur yang digunakan. Menyelaraskan ke tiga hal tersebut merupakan upaya untuk menutup kesenjangan hasil 
Evy l. Siregar et al.

belajar yang digambarkan melalui alat-alat tes seperti TIMMS, PISA dan PIRLS.

Kata Kunci: curriculum; educational process; educational assessment

'In times of drastic change, it is the learners who inherit the future'

(E. Hoffer)

\section{What's Happening Today and Tomorrow?}

The last couple of years have shown us that the era of globalisation creates interaction among citizens of the world. People at one end of the pole knows exactly what other people at the other end of the pole are doing, what they need, what they are achieving as well as losing, as there is no more barrier to anything. Its implication is far reached, that every walk of life is touched, come into contact with this experience, including the education sector. Locally designed standard has to compete with others internationally, up to where it means that people having a certain certification has an advantage over other certification. This, at the end, would also lead to a fierce competition in securing a place at a recognised universities or the job market as recognised certification and universities are believed to be a ticket for a better quality of life.

Along this line, studies show that the number of Asian students learning outside their own countries increases as opportunities open up. This occurs when people realize that certain certification or standard of achievement is sought more compared to some others, especially when it is compared to their own local certification. People try to make certain that they are holding the highest currency on offer, and those fortunate enough to go abroad would certainly do so, while other students would find a way to get recognised certification locally.

Having discussed the above point, it is fair to say that there has to be ways to prepare youngsters appropriately to be able 
Think Future, Act Present: Looking Beyond the Closed Door

to compete globally. Youngsters need to have the opportunity to develop their potential to the maximum in a favourable environment so that they have the ability to compete globally. Below is an illustration of developing the whole person through academic achievement. A programme that takes into consideration all aspects of human development, which would challenge maximal growth a person could have achieved.

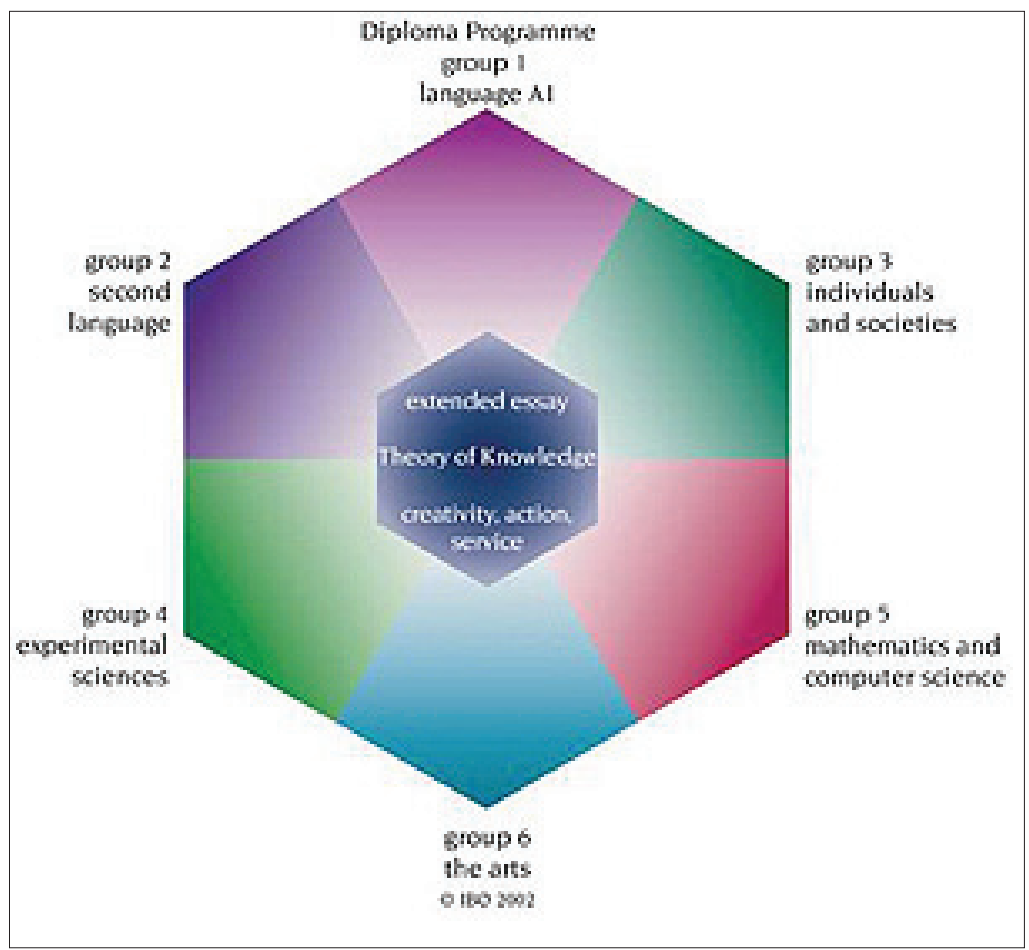

Figure 1: IB Programme

In this kind of programme learners are given the opportunity to develop as a whole person through choices in all aspects of subject area plus the option of exploring the non cognitive side of development such as character building through the structured programme at the centre (extended essay, theory of knowledge and creativity, action, service).

Looking at another type of programme on offer, the Cambridge Pre University programme discusses the development of 
Evy l. Siregar et al.

individual such as the following;

The Cambridge perspective to the pre-university curriculum is that it should recognise the value of a sound and strong national identity for young learners. It should encourage and develop international awareness and a respect and understanding for the values and traditions of others. It should also ensure that students are able to participate in, and contribute to, the global economy. Cambridge's International curriculum and assessments foster these skills and values and, when combined with a school ethos that works towards the same goals, provides a sound platform for students to move on into higher education in the destination of their choice. (Puntis and Sismey, 2004)

It is quite clear from the above discussions, that to be able to attain quality and standard of achievement it is important to pay attention to the process of education as well as to the subject coverage. Directing focus to the development of the whole person with character and values are as important as concentrating on the content of the curriculum.

\section{What Went Wrong?}

As has been discussed above, standard of achievement becomes an important issue that has to be dealt with in preparation for resilient youths that have the competence to survive the global contest. The two well known programme offered by both the IB Diploma and the A level programme are examples of developing youngsters who would have recognised competence acceptable all over the world, as the rigorous programme is accompanied with valid and reliable test. Their tests have the ability to speak about learners' competence on the area of study as featured by their certification. This is one important element in any certification, that the certificates have the ability to show clearly what is achieved; how far the subject is covered as well as how deep the learners' understanding is shown. This type of certification opens up possibilities as well as opportuni- 
ties for learners to grow as it caters to the development of the whole persons. It offers opportunities for learners to explore and construct their own knowledge along the path signify by the curriculum. In doing so, it creates opportunities of achievement for any type of learners and opens up the dynamic of educational effort that challenge the gifted while at the same time providing support for the weaker students.

In Indonesia, the issue of standard leads to debates only on results of outputs, where learners are streamed into compartmentalized subject's specialization and then are judged with only one type of paper per subjects known as 'Ujian Nasional' (UN). This test is the only tools used to measure and determine the achievement of the three whole years of schooling and is also used to determine whether learners pass the exam as an exit requirement of high school. The debate is still ongoing, but the important thing for consideration is, as the only measurement for achievement as well as the only aim of the whole educational effort, this type of test is limiting opportunity for development as well as restricting the dynamic of educational effort which eventually leads to poor quality of educational services where the process of education itself becomes neither challenging the gifted learner nor providing support for the weaker students.

As an example, the Figure 2 shows data collected from various sources that could give us an illustration of what is going on. The data show us achievement in the subject of mathematics. Most showed ability in doing the test very well. If we were to compare those students' achievement with the achievement of other students, on the same subject, we would see a significant difference.

The data in Figure $\mathbf{3}$ are from state schools situated in the same area; the only difference lies in the type of school. This one happens to be a regular state school with regular student intake. It seems that the UN test is much too easy for the previous students, while for the latter, the test is pretty difficult. And if we looked closer to the test itself, using taxonomy of thinking frame- 


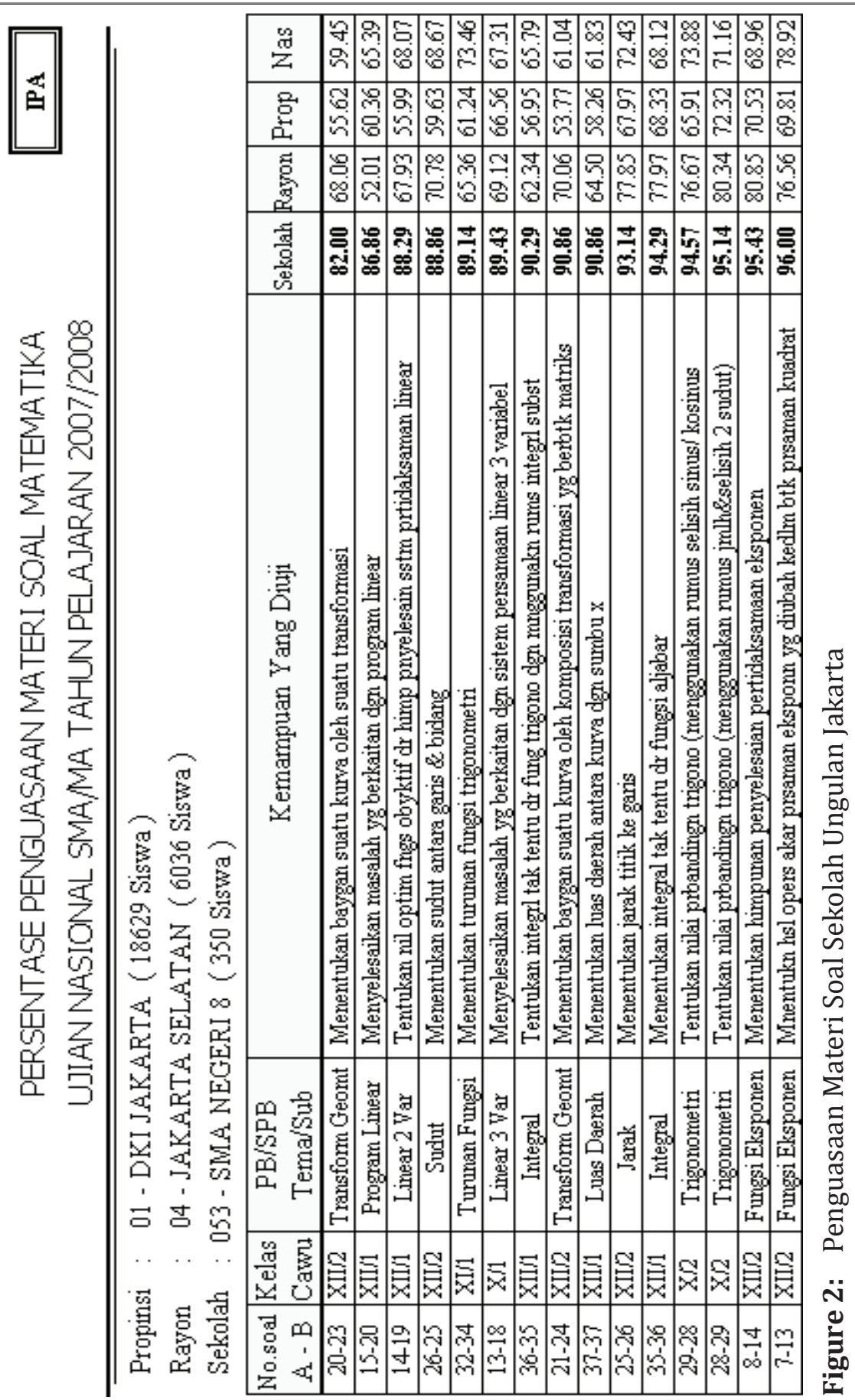


Think Future, Act Present: Looking Beyond the Closed Door

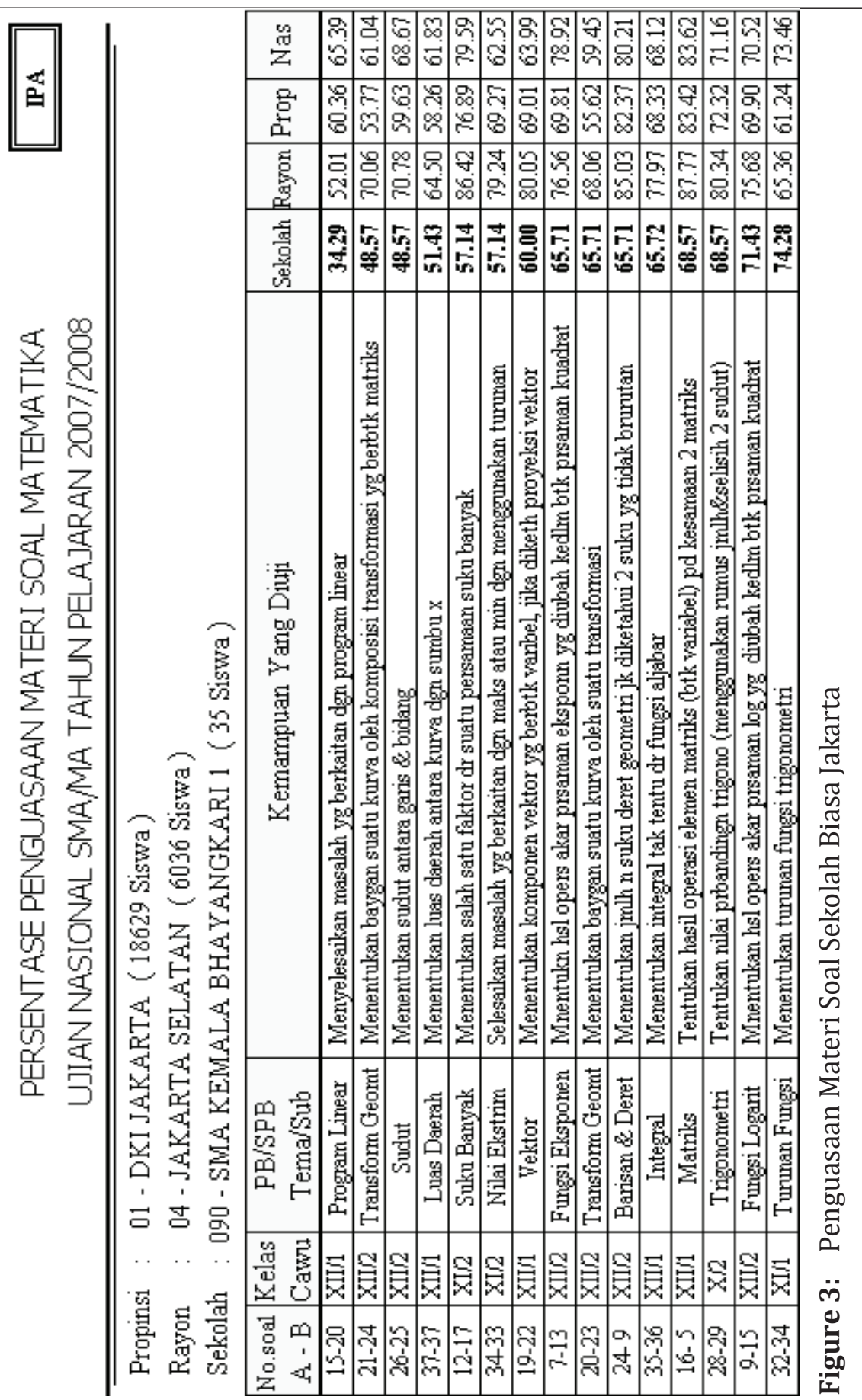


Evy l. Siregar et al.

work, most of the items are still at the knowledge level.

This lead us to believe that for gifted students there is not enough challenge in learning, while for other 'weaker' students there is not enough support to help them overcome obstacle. Having discussed the above result on the one hand, let's now turn to other studies on achievement using thinking taxonomy framework for the tool of measurement on the other hand. The study

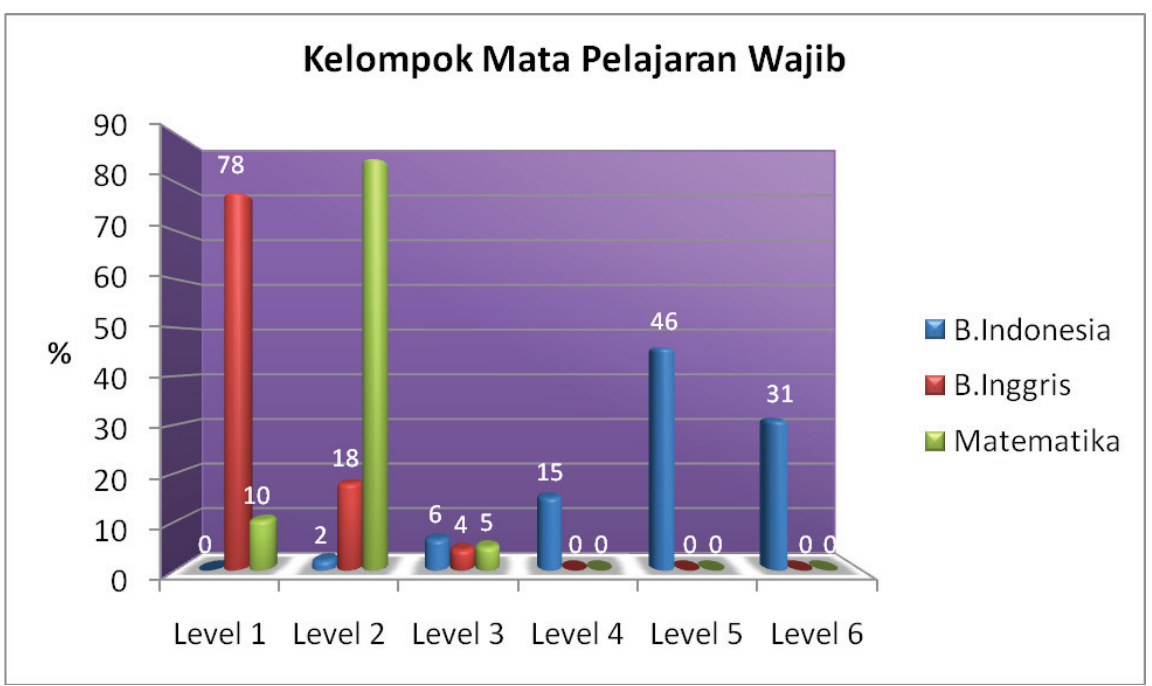

Figure 4: Hasil Baseline Study Bidang Studi Matematika

\begin{tabular}{lccccc}
\hline \multirow{2}{*}{$\begin{array}{c}\text { Subject of } \\
\text { Study }\end{array}$} & \multicolumn{5}{c}{ Total number of items based on Quellmalz Taxonomy } \\
\cline { 2 - 6 } & Recall & Analisis & Comparison & Inference & $\begin{array}{c}\text { Evaluation } \\
(\%)\end{array}$ \\
\hline Biology & 49 & 35 & $(\%)$ & $(\%)$ & $(\%)$ \\
chemistry & 7 & 36 & 11 & 15 & 0 \\
Physics & 10 & 77 & 7 & 7 & 9 \\
Mathematics & 5 & 35 & 25 & 15 & 0 \\
English (ESL) & 0 & 0 & 0 & 95 & 20 \\
Economics & 51 & 39 & 10 & 0 & 5 \\
Rata-rata & 20 & 37 & 9 & 28 & 0 \\
\hline
\end{tabular}

Figure 5: Item Taxonomy for Baseline Study 
Think Future, Act Present: Looking Beyond the Closed Door

\begin{tabular}{|c|c|c|c|c|c|c|c|}
\hline \multirow[b]{2}{*}{ Country } & \multicolumn{3}{|c|}{ Content domain } & \multirow[b]{2}{*}{$\begin{array}{l}\text { Data and } \\
\text { chance }\end{array}$} & \multicolumn{3}{|c|}{ Cognitive domain } \\
\hline & Nunber & Algebra & Goometry & & Knowing & Applying & Reasoning \\
\hline TIMSS scale averaqe & 500 & 500 & 500 & 560 & 500 & 500 & 500 \\
\hline Chlnese Tajpel & 577 & 617 & 592 & 566 & 592 & 594 & 591 \\
\hline Korea, Rep. of & 583 & 596 & 587 & 580 & 596 & 596 & 579 \\
\hline Singapore & 597 & 579 & 578 & 574 & 593 & 581 & 579 \\
\hline Horng Kong SAR 12 & 567 & 565 & 570 & 549 & 569 & 574 & 557 \\
\hline Japan & 551 & 559 & 573 & 573 & 565 & 560 & 568 \\
\hline Hungary & 517 & 503 & 508 & 524 & 513 & 518 & 513 \\
\hline England ${ }^{2}$ & 510 & 492 & 510 & 547 & 514 & 503 & 518 \\
\hline Russlan Federailon & 507 & 518 & 510 & 487 & 510 & 521 & 497 \\
\hline United Stateg 2,3 & 510 & 501 & 480 & 531 & 500 & 514 & 505 \\
\hline Lthuan|at & 506 & 483 & 507 & 523 & 511 & 508 & 486 \\
\hline Czech Republic & 511 & 484 & 498 & 512 & 504 & 502 & 500 \\
\hline Slovenla & 502 & 488 & 499 & 511 & 503 & 500 & 496 \\
\hline Arnerla & 492 & 532 & 493 & 427 & 493 & 507 & 489 \\
\hline Austialla & 503 & 471 & 487 & 525 & 500 & 487 & 502 \\
\hline Sweden & 507 & 456 & 472 & 526 & 497 & 478 & 490 \\
\hline Malla & 496 & 473 & 495 & 487 & 492 & 490 & 475 \\
\hline Scoulland? & 499 & 467 & 485 & 517 & 469 & 481 & 495 \\
\hline Sefbla3/4 & 478 & 500 & 486 & 458 & 478 & 500 & 474 \\
\hline Italy & 478 & 460 & 490 & 491 & 483 & 476 & 483 \\
\hline Malaysla & 491 & 454 & 477 & 469 & 478 & 477 & 468 \\
\hline Norway & 498 & 425 & 459 & 505 & 477 & 458 & 475 \\
\hline Cyprus & 454 & 468 & 458 & 464 & 465 & 468 & 461 \\
\hline Bulgarla & 458 & 476 & 468 & 440 & 458 & 477 & 455 \\
\hline Ukraine & 450 & 464 & 467 & 458 & 464 & 471 & 445 \\
\hline Romaria & 457 & 478 & 466 & 429 & 462 & 470 & 449 \\
\hline |вวер & 459 & 470 & 436 & 465 & 456 & 473 & 462 \\
\hline Bosnla and Herzegouina & 451 & 475 & 451 & 437 & 440 & 478 & 452 \\
\hline Lebanon & 454 & 465 & 462 & 407 & 448 & 464 & 429 \\
\hline Thaland & 444 & 433 & 442 & 453 & 446 & 436 & 456 \\
\hline Turkey & 429 & 440 & 411 & 445 & 425 & 439 & 441 \\
\hline Jordan & 416 & 448 & 436 & 425 & 422 & 432 & 440 \\
\hline Tunisla & 425 & 423 & 437 & 411 & 423 & 421 & 425 \\
\hline Georgla $a^{4}$ & 421 & 421 & 409 & 373 & 401 & 427 & 389 \\
\hline Iran, Islamlc Rep. of & 395 & 448 & 423 & 415 & 402 & 403 & 427 \\
\hline Bahrain & 398 & 443 & 412 & 418 & 403 & 395 & 413 \\
\hline Indonesla & 399 & 405 & 395 & 402 & 398 & 397 & 405 \\
\hline Syrlan Arab Republe & 393 & 406 & 417 & 387 & 401 & 393 & 596 \\
\hline Egypt & 393 & 409 & 406 & 384 & 393 & 392 & 396 \\
\hline Algeria & 423 & 349 & 432 & 371 & 412 & 371 & - \\
\hline colombla & 369 & 390 & 371 & 405 & 384 & 364 & 416 \\
\hline Cman & 363 & 391 & 387 & 389 & 368 & 372 & 397 \\
\hline Palesulrlan Nat'| Aulth. & 366 & 362 & 388 & 371 & 371 & 365 & 381 \\
\hline Bolswana & 366 & 394 & 325 & 384 & 351 & 376 & - \\
\hline Kuwals & 347 & 354 & 385 & 366 & 361 & 347 & - \\
\hline El Salvaøor & 355 & 331 & 318 & 362 & 347 & 336 & - \\
\hline Saud Arabla & 309 & 344 & 359 & 348 & 335 & 308 & - \\
\hline Ghana & 310 & 358 & 275 & 321 & 297 & 313 & - \\
\hline Qaktar & 334 & 312 & 301 & 365 & 365 & 307 & - \\
\hline \multicolumn{8}{|c|}{ 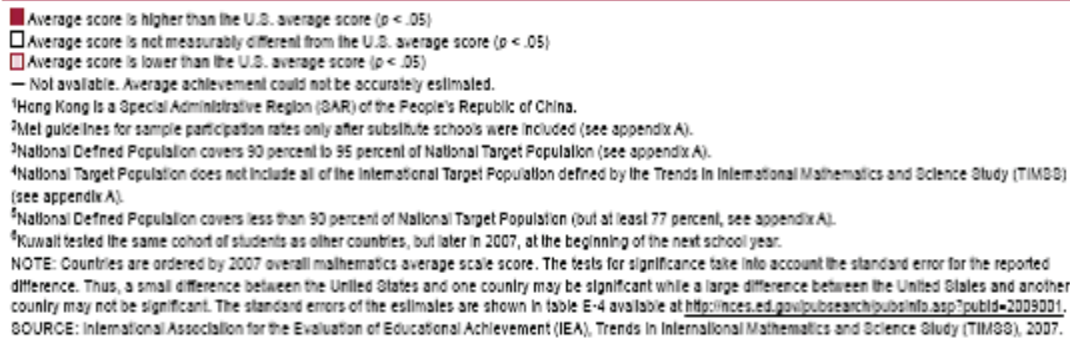 } \\
\hline
\end{tabular}

Figure 6: TIMSS, Average Mathematics Content and Cognitive Domain Scores of Eight-Grade Students, by Country, 2007 
Evy I. Siregar et al.

\begin{tabular}{|c|c|c|c|}
\hline \multicolumn{2}{|l|}{ Grade four } & \multicolumn{2}{|c|}{ Grade elght } \\
\hline Content domains & $\begin{array}{r}\text { Percent of } \\
\text { sssassment }\end{array}$ & Content domains & $\begin{array}{l}\text { Percent of } \\
\text { sasesament }\end{array}$ \\
\hline Number & 52 & Number & 29 \\
\hline Geometric shapes and measures & 34 & Algebra & 30 \\
\hline \multirow[t]{2}{*}{ Data display } & 15 & Geometry & 22 \\
\hline & & Data and chance & 19 \\
\hline Cognitive domains & $\begin{array}{l}\text { Percent of } \\
\text { assasament }\end{array}$ & Cognitive domains & $\begin{array}{l}\text { Percent of } \\
\text { assesament }\end{array}$ \\
\hline Knowing & 39 & Knowing & 38 \\
\hline Applying & 39 & Applying & 41 \\
\hline Reasoning & 22 & Reasoning & 21 \\
\hline \multicolumn{4}{|c|}{ 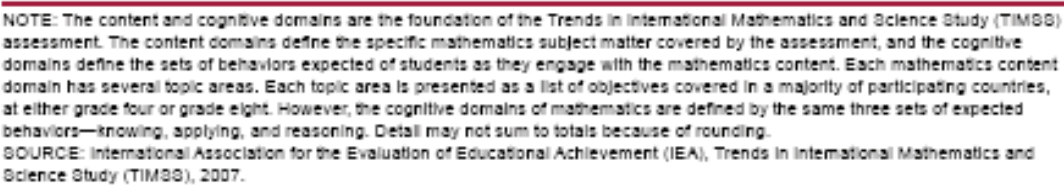 } \\
\hline
\end{tabular}

Figure 7: TAXONOMY TIMSS, Percentage of Fourth- and Eight-grade TIMSS Mathematic Assessment Devoted to Content and Cognitive Domains, 2007

shows that both type os school (with regular and gifted ones) perform almost the same on the subject of mathematics.

The result of the above studies is comparable to another measurent tools which is similarly applying the framework of thinking taxonomy in their work. The result of both studies show the same degree of achievement. Students do well only at the level of knowledge, the lowest thinking skills ability.

These studies lead us to believe that there is incongruence somewhere in the delivery process as well as at the exit exams. We could not leave things as they are as our youth needs to be prepared for their future in the global world that is full of challenge, opportunities as well as fierce competition.

\section{How do We Make Things Right?}

For the last five years, effort to raise standard began to be set in motion. The growing concern for the progress of education processes and results in Indonesia has led to the implementation of SBI program in government schools. DKI Jakarta is among the first provinces in Indonesia to have pioneered the program 
by establishing classrooms with international curricula, namely Cambridge IGCSE and A Level.

Accordingly, the SBI program adopted a different approach to the usual process of schooling tradition currently in practice. The approach taken is promoted not too far off from the Cambridge International programme. As Puntis (2004) maintains as follows;

The effective design of a school curriculum through the coherent aims and assessment objectives of each of the subjects that comprise it plays a vital part in securing $g$ the achievement of such skills. A cross-curriculum approach, for example, that encourages students to manage their own learning - by setting tasks that involve research and investigation and which encourage reflection on outcomes - is vital. In IGCSE, in AS and A Level there are opportunities for extended essays and for individual research projects that emphasise the importance of these skills and which encourage students to experiment, to try new approaches and to deal with risk in their learning. As learners we learn all too soon the embarrassment of failure and learn to play a very safe game which militates against the development of the skills of critical enquiry. Thomas Edison had many, many failed attempts in developing the light bulb - but when an assistant asked whether he felt a failure he was able to reply very simply that on the contrary he now knew a considerable number of ways not to design a light-bulb. So we must empower our students to experiment, to try new ways and to learn from their mistakes rather than asking us as teachers for the clues to immediate success in task outcomes. We need to encourage effective learners for who are resilient - they will give it a go even when the outcome and the way to proceed are uncertain. And although CIE's mark schemes are closely specified, examiners are given the authority in their marking to recognise and reward an unexpected solution, or new interpretation of the questions. 
Evy I. Siregar et al.

As illustrated above, the programme focuses the alignment of curriculum, process delivery and the assessment for certification. In this respect, for an effective learning process to occur, clear and achievable learning goals have to be set. These learning goals must be related to students' lives and/or personal interests to help raise learning needs and motivations. Integrating their experience into their learning is also seen as essential for students to be able to construct their knowledge, as well as sharpen up their skills, as have been set in the learning goals. Having a personal stake makes for the learning needs and experience very personal. Furthermore as the design of the learning process built in more variety of tasks where learners need to explore on their own or with their peers, it is hoped that it will lead to students' own independent learning. All of these will help learners to go for more thorough activities that would lead to a deeper learning, and thus a more beneficial process in constructing their knowledge.

Moreover, as the programme follows an assessment process where learners are involved, the learners themselves are introduced to the skill of planning to overcome their weakness as well as building on their strength as an integrated learning process. This kind of assessment opens up opportunity in developing assessment as a tool for learning. In going through this process, learners have the opportunity to master not only the subject content, but also to acquire other soft skills required for further studies as required by the curriculum.

Another point that should be observed when this whole process is adequately carried out is that learners would be ready to be assessed with any measurement tools as they are equipped to sit not only for a certain type of test. Learners are trained to use their thinking skills to face most academic problems, and in doing so they would be ready to sit for most type of assessment.

\section{How do We Prepare for Achievement?}

Setting up such goals for learners has its consequence in structuring the whole learning environment and most important 
of all, an effort is focused on preparing the teachers as the tip of the arrow to lead the learning activities. The teachers are not only capable in their subjects, but they have to master the skills as leader, facilitator, and designer of learning as well as companion in the journey of constructing knowledge. Teachers are prepared through training for classroom preparation where they have to be able to create and design learning tasks that is challenging on the one hand but also catering for all the different learners on the other hand. It is a very demanding work, but as teachers are working together with support from peers as well as supervisors, the process itself is a learning journey for all concerned. This poses as an example for learners as well.

Aside from the training itself, teachers are also well supported as part of their professional development with 'small reflective workshop' held regularly and often times informally, that all involved are focused on the vision and mission of the whole educational process. At these meetings, teachers reflect on activities, working on its pluses as well as minuses including working on the 'failed' activities. In this way, everyone concerned have the opportunity to talk about and share what makes success in addition to why learning do not occur. An atmosphere of learning is created even though the topic is about what does not work, and judging others is not on the agenda. This in itself is also a learning experience for everyone.

In addition, teachers also create their own portfolios as a means of their own learning as well as teaching record which in turn is a means of monitoring teachers' own work. In this way, quality is assured and learners are kept in the forefront of all the learning process.

All the above efforts are aimed solely for a fruitful and enjoyable learning experience that will stamp a lasting impression on what learning is. For experience have shown us, successful learning is not only the excellent result written on the certificate, but is seen in the attitude and character discernible in the learner themselves. 
Evy l. Siregar et al.

The following discussion is what we have been doing in trying to get where we want to go in practice.

\section{Why Designing Tasks?}

'Tell me and I will forget, Show me and I may remember; Involve me and I will understand.' (Confusius)

Mobile phones are probably the most popular communication gadgeets in the world today. Many of their features have been found to be really useful, such as the text messaging or chatting, which allow us to send messages to other people. Most mobile phones have a report feature that let us know when our text messages have been sent and delivered. Furthermore, the smarter ones of those phones also tell us when the messages have been read. Being teachers, we often wish that there is some similar device, which tells us when the "messages" of the curriculum we have been "sending" have been "delivered" to and "read" by our students. And here comes the question of how then, do we make sure that our messages get through? Now, such device may not exist, but task design does.

So, what is task design? How does it differ from lesson plan, and how would it help conveying our messages? The following figure and paragraphs will attempt to answer these questions.

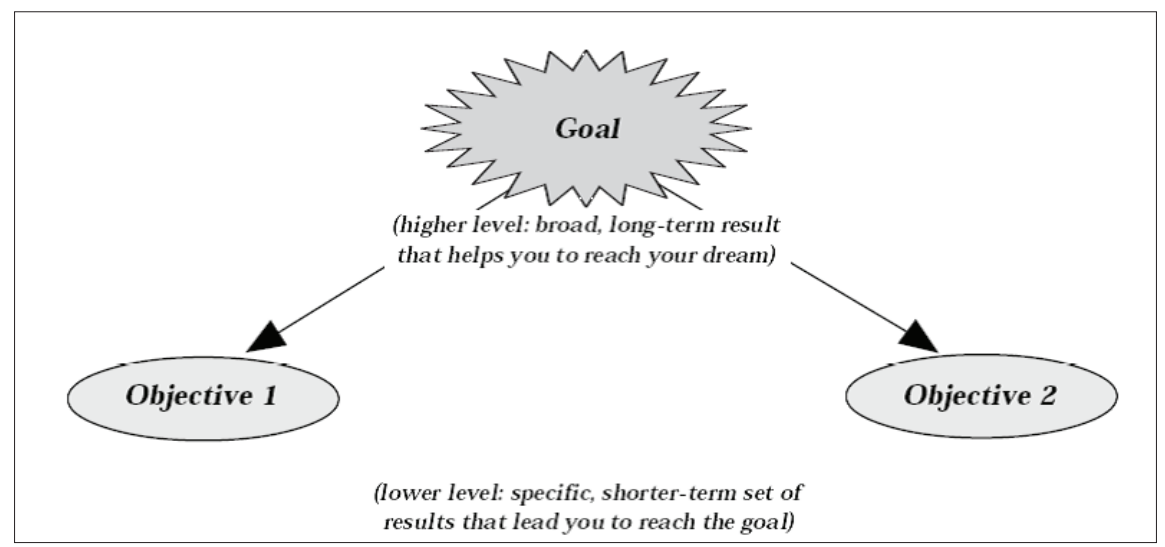

Figure 8 
Objectives describe the things you will do to achieve your goal. If all of the objectives are successfully done, this means you should have achieved your goal. One goal $=$ a number of objectives.

EXAMPLE of how objectives flow from the goals

If Batman's project goal is:

- To reduce violent crime in Gotham City.

Then his objectives might be to:

- Increase the number of superheroes living in Gotham by $100 \%$ by the end of the year.

- Double the high-tech crime fighting tools available to police within two years.

- Strengthen the current police force's "bad guys" surveillance system within 2 months so it includes all people convicted in last 6 months.

[Yukon Literacy Coalition (2005)]

Hence, every lesson plan contains a goal, which is to convey one or more messages of the curriculum, and every task contains an objective to make sure the messages are conveyed. Task design may mean differently to different instructional designer; to us, task design is the tool of our efforts to engage students in learning, to help them construct and develop knowledge, skills and characters through and/or using experience, and to give them chances to apply and practice their knowledge and skills.

Task designs must be based on and aligned with curriculum and assessments. We, teachers, are like drivers or pilots assigned to lead and facilitate students as the passengers of our "classbus" or "classplanes" to "destinations" stated in the curriculum and measured by assessments. That means we must first understand what knowledge and minimum competence the curriculum requires our students to achieve at the end of the learning process (final destination), before we can design effective learning tasks (milestones). Furthermore, we must also find out how wide the 
Evy l. Siregar et al.

gap between students' present competence and the desired competence is, so that we know how far we need to go and where to start from.

Once we have found out our starting points and the goal that our students have to achieve, we can set smaller achievable objectives and construct activities that will generate the basic concept of a topic. Activities are important since students will pass through experiences of their own and come to conclusions of their own. It is important for students to feel and experience so that they would have the experience as if they are the first scientists finding or building a theory. Once they made their conclusions, we have to figure out how they have come to those conclusions. We could ask the students to explain the reasoning that leads to their conclusion, as their answer could vary, and we could help them focus on their concept-construction.

As soon as we are sure that they have grasped the basic concept, we may begin to create a variety of tasks that would further accommodate and ensure students' learning process. Thus, we need to design tasks that invoke and fulfil their learning needs, cater for their differences, challenge their skills, and assess their progress.

\section{Where are We Going? Why are We Going There?}

When we were students, we frequently felt like being ushered onto a bus or a plane and taken to a destination without knowing the reason of going there. Thus, we often wondered, "Why do I have to learn Geometry? What's it got to do with me?" or "Why must I know about cells, organelles and their functions?" or "Why bother with chemical structures?" and so on. And as teachers today, we still hear similar questions being posed time and again by our students, as they try to make sense of their learning.

On the other hand, the curriculum obliges them to learn and know about things that are seemingly remote from or even unattached to their lives. Yet, as adults and teachers, we know 
that nothing is further from the truth. We know that most curricula have been designed with students' current and future lives in mind; meaning that they do not only concern about subject content, but also skills-cognitive, affective and psychomotor-and characters. So, what do we do then? As instructional designers, it is our job to help students understand why they have to know about or be able to do things by invoking and fulfilling their learning needs through the setting of clear and achievable learning objectives in familiar contexts; thus, giving them meaningful learning processes and experiences, as well as leading them to reflect in their learning and characters the quality and standards required by the curriculum.

\section{How are We Getting There?}

Now that we know where to go and why we go there, we must figure out how we're going to get there. Before an effective learning process can occur, students need to connect with the objectives that they are required to achieve, so that their learning needs are invoked. Hence, we need to design tasks with clear and achievable objectives that are immediately related to students' lives. We wouldn't have wondered why we had to learn about Geometry had we've been asked to measure the size of our own classrooms or design comfortable cages or houses for our pets. We would've understood the purpose of knowing the functions of cells and organelles had we've been asked if anyone or why someone in our families had cancer or other serious illnesses and how they might be cured. We also would have the need to bother with chemical structures had we've been asked to find out if the cooking oil used by our mothers at home were save for our health and the environment.

Other than objectives, our design task should also contain materials, approaches and methods that are suitable for our students. Each student is a unique individual. They have their own multiple intelligences, learning styles, interests, cultural and family backgrounds and learning paces. These differences may 
Evy I. Siregar et al.

seem to be obstacles, but they really are learning assets, which we can utilize to our students' advantage. Most of us learn better when we are in good psychological and emotional condition, or in other words, when we have fun. And we could have more fun in and out of the classroom with learning activities containing tasks that engage students through listening, singing along with and writing songs, watching movies with interesting plots, playing physical group games, cooking and eating favourite foods, going shopping, doing some gardening, reading and writing poems and stories, creating posters or building realia, having group discussions and debates, working on thematic team projects, and so on. Furthermore, in creating these tasks, we have to pay attention to their levels of difficulty. The difficulty levels of the task must also be differentiated-based on contents and skills-and gradually elevated, as each different level of difficulty would lead students to a new depth of emphasize on the knowledge and skills that they are learning in their own paces.

\section{How do We Know that We're Getting There?}

You might ask, "How do we know that we're not having too much fun or only fun and not enough learning?" Now this is where assessments play an important role. This is the time when we activate the report feature of the message-delivery device we call task design. So what is this report feature? It is called Assessment for Learning (AfL).

AfL is, in fact, incorporated throughout a designed task, carried out together by both students and teachers during the process of tasks completion, as implied in its definition below:

[AfL is]... a process of seeking and interpreting evidence for use by learners and their teachers to decide where the learners are in their learning, where they need to go, and how best to get there. (Assessment Reform Group, 2002)

AfL starts with the sharing of learning intentions and success criteria with students. When students understand where they are going and why they are going there, they are usually 
more willing to go through the sometime rough learning journeys, as they feel that they have some control over the course of the journey instead of following blindly. Understanding the success criteria or what is expected of them often boost their motivation to meet those criteria. It is like playing computer games; you'd advance to the next level if you've completed certain tasks or overcome certain obstacles or both. Teachers' effective questioning can serve as the tools to help students complete the task and/ or overcome the obstacles. Open ended questions stimulate more thinking; therefore, instead of direct answers, directive questions are more useful for teachers to give.

As mentioned above, AfL is not only conducted by teachers. By evaluating and reflecting upon their own work and those of their peers, students would be able to identify their own strengths and weaknesses. And other than from teachers, they would also be taking and giving feedbacks from and to one another, on how to advance their strengths and alleviate their weaknesses.

Yet, different forms of feedbacks bring about different impacts. A research was conducted in 4 Israeli schools, involving 132 low and high ability year 7 pupils in 12 classes with the same teaching, aims, teachers and classwork, but with 3 different kinds of feedback: marks, comments and marks+comments. The result of that research is presented in Figure $\mathbf{9}$.

The research result above shows that feedbacks in the form of marks alone and marks+comments do not bring any changes to the students' progress. Furthermore, it gives positive motivational impacts only to the more able student group, and not to the less able one. In contrary, feedbacks in the form of comments alone bring about a $30 \%$ improvement on the students' progress and positive motivational impacts on both groups.

\begin{tabular}{cccc}
\hline \multirow{2}{*}{ Feedback } & \multirow{2}{*}{ Progress } & \multicolumn{2}{c}{ Effect on motivation } \\
\cline { 3 - 4 } & & Top Students & Bottom Students \\
\hline Marks & none & + ve & -ve \\
Comments & $\mathbf{3 0 \%}$ & + +ve & + +ve \\
Marks \& comments & none & +ve & -ve \\
\hline
\end{tabular}

Figure 9 (Butler, 1988:1-14) 
Evy l. Siregar et al.

\section{Memorable Journeys}

The Cambridge IGCSE and A Level curricula were designed with emphasis on deep understanding, which involves higher order thinking skills, and the constructive active learning model. They also try to ensure that students become empowered individuals who take responsibility of and reflect on their own and each-other's learning, while maintaining teamwork and social skills. All this was elaborated in a paper written by Ann Puntis and Val Sismey of the University of Cambridge International Examinations (CIE).

CIE's commitment to this agenda is mediated through a curriculum and assessment model that emphasises the acquisition of 'deep understanding' in learning - where that deep understanding is likely to involve higher order cognitive activities as described in a number of cognitive taxonomies (Bloom,1956, Vygotsky, 1987).

The 'deep understanding' that characterises the Cambridge curriculum follows a constructivist model of active learning. IGCSE modes of assessment, for example, emphasise investigative approaches to learning and the application of skills, knowledge and understanding. The approach recognises that 'recall' becomes a relatively less useful skill for individuals in today's world of rapid change - instead understanding, applying, analysing, evaluating and creating - the higher order skills of a re-worked Bloom's taxonomy assume vital importance for all and not simply the gifted few.

..... A cross-curriculum approach, for example, that encourages students to manage their own learning - by setting tasks that involve research and investigation and which encourage reflection on outcomes - is vital.

And to the final skill in empowering individuals - the skill of being able to work together, to collaborate as part of a team. Too much of the educational process can be seen as being involved with personal achievement. From 
the assessment perspective this is appropriate. But there are many opportunities in the classroom for peer-to-peer learning and teamworking. The ends this achieves are not merely social, although these are, of course, important. They are also educationally vital. To learn from our peers as well as from our teachers increases the pace and opportunity for learning (Puntis \& Sismey, 2004).

Such curriculum design consequently and significantly determines the instructional designs for classrooms. We are grateful to have shared with our students the journeys onboard the Cambridge IGCSE and A Level curriculum "airplanes". The "flights" were often bumpy and didn't get to the destination as "scheduled"; yet, they were always rewarding us with experiences to learn from. In the following paragraphs we hope to share with you some of those memorable journeys.

\section{IGCSE English as a Second Language (ESL)}

One of the IGCSE ESL curriculum messages is that students are able to write formal letters; be it to future employers or authorities, such as school principals or town/city councils or other government officials.

It was a class of 25 students aged 14-15 years old, whose English competence were ranging from elementary to upper intermediate. In the attempt to achieve the curriculum goal, they were divided into groups of 3-4 members of difference competences, and each group was provided with a few varied samples of formal letters and various familiar and non-familiar contextual situations to base their letter-writing on. And their tasks were:

1) Find similarities among the samples of formal letter and conclude the characteristics of formal letters. (15 minutes)

2) With the class, share your conclusion, decide what constitutes as a good formal letter and explain the reasoning. After that, write the criteria rubric together. (30 minutes)

3) Make a new group and write together a formal letter based 
Evy I. Siregar et al.

on both the contextual situation given and the criteria rubric you've written. (20 minutes)

4) Share your letter with the class and check it against the criteria rubric. (15 minutes)

5) Take feedbacks from your classmates, and revise your letter. (15 minutes)

6) Individually, write a formal letter based on the contextual situation and criteria rubric provided. (15 minutes)

7) When you have finished, find a partner, check and give comments on each other's work, then revise your work when necessary. (15 minutes).

These tasks were quite effective as students understand that at the end of the lesson, they are expected to be able to write an appropriate formal letter for various purposes and audiences, both in the contexts of familiar and novel situations. Moreover, they started by constructing their knowledge and skills of formalletter-writing through "experiencing" the different formal letters by being their audiences, which then continued by practicing their higher order thinking skills as they compared the various letters, concluded their characteristics and created the criteria rubric. In addition, working in small and large groups gave them the chance to practice their social skills, learn from each other and reflect on each other's learning. And finally, they were given a chance to assess and reflect on their own individual learning by writing and revising their own formal letters.

\section{A Level Biology}

Learning A level syllabus has several purposes, one of them is to provide a worthwhile educational experience for all students to enable them to acquire sufficient understanding and knowledge to be suitably prepared for studies beyond $\mathrm{A}$ Level in biological sciences, in further or higher education, and for professional courses.

This syllabus leads the students to develop abilities and skills 
that are relevant to the study and practice of biological science and are useful in everyday life. It should be able to stimulate students and create a sustained interest in biology so that the study of the subject is enjoyable and satisfying.

It is anticipated that programmes of study based on this syllabus will feature a variety of learning experiences designed to enhance the development of skill and comprehension. (A level Biology Syllabus, 2007)

A Level Biology learns about the basic knowledge of biological science with emphasis on human metabolisms and other related topic. This subject also has strong connection with A Level Chemistry, especially organic chemistry, formula structure and equation. Students might love Biology because it is easy to relate this subject to their daily lives, but when it is related to chemistry, it becomes abstract information which is usually an obstacle for the students to comprehend biology. This is a challenge that every biology teacher should face. We should create interesting learning activities that can trigger the students' learning needs so that we can promote learning process in the classroom. To make sure the learning process goes well, we should be prepared with a well-designed task.

The following are examples of multiple design tasks in A Level Biology classroom with 25 students. This task designs cover several learning outcomes from different topics. It is possible to do such thing in the classroom through a case study. It took 2 weeks ( 6 meetings) to cover all of the learning outcomes with a very satisfying process that promoted learning among the students and triggered their curiosity and interests.

These are the learning outcomes from A level Cambridge 2007 syllabus:

\section{A. CELL STRUCTURE}

Outline functions of organelles in plant and animal cells.

- Outline the functions of the membrane systems and 
organelles: rough and smooth endoplasmic reticula, Golgi apparatus, mitochondria, ribosomes, lysosomes, chloroplasts, plasma/cell surface membrane, nuclear envelope, centrioles, nucleus and nucleolus;

\section{B. BIOLOGICAL MOLECULES}

The structure of carbohydrates, lipids and proteins and their roles in living organisms.

- $\quad$ Describe the molecular structure of a triglyceride and a phospholipid and relate these structures to their functions in living organisms;

- $\quad$ use the knowledge gained in this section in new situations or to solve related problems.

\section{ENZYMES}

Mode of action of enzymes

- $\quad$ explain the mode of action of enzymes in terms of an active site, enzyme/substrate complex, lowering of activation energy and enzyme specificity;

- $\quad$ explain the effects of competitive and non-competitive inhibitors on the rate of enzyme activity;

- use the knowledge gained in this section in new situations or to solve related problems.

\section{REGULATION AND CONTROL}

Nervous and hormonal communication

- describe the structure of a sensory neurone and a motor neurone and outline their functions in a reflex arc;

- describe and explain the transmission of an action potential in a myelinated neurone (the importance of sodium and potassium ions in the impulse transmission should be emphasised); 
Think Future, Act Present: Looking Beyond the Closed Door

- $\quad$ explain the importance of the myelin sheath (saltatory conduction) and the refractory period in determining the speed of nerve impulse transmission;

\section{E. INHERITED CHANGE}

The nature of genes and alleles and their role in determining the phenotype Monohybrid and dihybrid crosses

- $\quad$ explain the terms locus, allele, dominant, recessive, codominant, homozygous, heterozygous, phenotype and genotype;

- use genetic diagrams to solve problems involving monohybrid and dihybrid crosses, including those involving sex linkage, codominance and multiple alleles (but not involving autosomal linkage or epistasis).

\section{These were the Tasks:}

1) Students watch a movie related to the learning outcomes. The movie title is Lorenzo's oil. This movie is about a boy who suffered from Adrenoleukodystrophy (ALD) a rare Xlinked inherited metabolic disorder.

2) Students answer the questions related to the movie. These are the questions:

- What is the full name of this disease? Why is it a degenerative disease?

- List some symptoms of ALD. What is the definitive sign?

- Explain the effect of living in the Comoros Islands had on this disease.

- Explain and draw diagram why ALD usually only affects males.

- Why didn't the first diet therapy work?

- In the second diet therapy, why did they decide to use oleic acid?

- How did the third diet therapy affect Lorenzo's blood fat level? 
Evy I. Siregar et al.

- Why was erucic acid more effective than oleic acid in lowering Lorenzo's blood fat level?

- What is Lorenzo's Oil made from?

- At this time, is there any way to reverse the effects of ALD? Why?

3) Whole class discussion. Students answer the questions and hold a class discussion based on the video. Then, some of the students are asked to explain it in front of the class.

4) The discussion is developed into a further and detailed discussion.

5) Students make 5 groups. Each group is given different tasks to be discussed.

6) The answer of the questions (the tasks) is presented in front of the class, the teacher facilitates learning discussion.

7) Assessment is conducted through performance rubric.

8) Students will relate the discussion with biological basic concept explained in learning outcomes.

\section{Group 1}

Students were given questions about basic lipid structure and the application of lipid structure in the movie. These are some of the questions:

a) What are the differences between saturated and unsaturated fatty acids related to their function and structure!

b) Where can you find steroid in human body? Explain its structure and function!

c) Explain the mechanism of feedback reaction that involves the steroid!

d) How is cholesterol formed? Explain its function!

e) How do you differentiate HDL and LDL? Explain!

f) Why would very long chain saturated fatty acids induce ALD whereas very long chain unsaturated fatty acids would not?

The discussion about this topic brought a deeper under- 
Think Future, Act Present: Looking Beyond the Closed Door

standing about the relationship between the structures of lipid and their functions, and that the differences in those structures also lead to ADL disease. This discussion was then taken further to a discussion about cholesterol in human blood.

\section{Group 2}

Students were given questions about organelles involved in the lipid synthesis and asked to draw organelles from a typical animal cell and explain the function of each organelles. These were done in front of the class.

a) Does Lorenzo's Oil acts at the endoplasmic reticulum or the peroxisome?

b) Draw and explain the function of cell organelles!

\section{Group 3}

Students explain the mechanism of competitive inhibitor that occurs in ALD and is related to basic enzyme mode of actions. This is example of the questions:

a) What is an enzyme? How do they affect a chemical reaction?

b) How can enzymes be used in industry?

c) How do changes in temperature and enzyme concentration affect an enzyme's behaviour?

d) Illustrate and explain the lock and key model of enzyme behaviour.

e) What is the difference between competitive and non competitive inhibitor? How do they differ? Explain!

f) The movie describes the action of what two enzymes? What do the enzymes do and where are they located? (VLCSFAs are degraded in the peroxisome by a pathway that begins with the enzyme called VLCFA-CoA synthase; this is the enzyme that is missing from the peroxisomes of Lorenzo. The second enzyme is the enzyme that makes the VLCSFAs, and it is located in the endoplasmic reticulum). Students come up 
Evy I. Siregar et al.

with the animation on how the enzyme works.

\section{Group 4}

Students explain the impact of ALD in nervous system and transmission of nerve impulses. These are some examples of the questions:

a) What is myelin sheath? How does ALD affect the myelin sheath of lorenzo's neurons?

b) Explain the difference between transmission of nerve impulses in normal people and with person affected with ALD!

c) Explain what is meant by saltatory conduction!

d) Explain the importance of the myelin sheath and the refractory period in determining the speed of nerve impulse transmission!

\section{Group 5}

Students answer the questions related to the inheritance of ALD and its basic genetic concept.

a) Does Lorenzo have one or two copies of the gene that causes ALD? Does his mother or father have one or two copies? For each person, note whether the copy is defective (recessive) or normal (dominant).

b) True or False: Most inherited diseases like ALD or cystic fibrosis are recessive diseases. What does the phrase "recessive disease" mean? (Due to expression of recessive allele; inherited diseases due to dominant allele are very rare)

c) If most inherited diseases are due to the recessive allele, and many patients die before they reproduce, why does the recessive allele remain in the population? (1: in some diseases, patients of some may live long enough to reproduce and (2): the "heterozygote advantage" could be responsible. The heterozygote carrier of sickle cell anemia is resistant to malaria; heterozygtote carriers of the recessive allele for Tay-Sach's 
disease may be more resistant to tuberculosis, heterozygotes for the recessive cystic fibrosis allele may be protected against cholera-induced diarrhoea. Thus, heterozygotes may have an advantage and would keep the dangerous recessive allele in the population).

d) Why are boys more likely to have an inherited (recessive) disease than a girl? Use the Punnett square.

e) What if Lorenzo was able to have children: what would be the odds of having a child with ALD if Lorenzo married a carrier (calculate for a female child and then a male child) or a non-carrier individual? Use the Punnett square.

f) Go through the genetics of a non-sex linked recessive disease; that is, show the genotype of parents where there are two copies of the gene involved in an inherited recessive disease. Must both parents be heterozygotes or carriers for a child to be stricken? Will both girls and boys be affected with equal probability? What is the probability of two carriers producing a normal child?

g) With ALD, why is it not possible for a female to have the genotype of homozygous recessive (from figures, aa)? Why, in some other inherited diseases, is it possible to have this genotype (aa)? (modified from Stith, J.B)

To check students' learning, Assessment for learning through Performance rubric is applied. The Rubric criteria are as follows:

- The discussion of the question

- The accuracy of the answer

- Ability to explain to the whole class

- Relationship with basic concept

- Interaction with audience

\section{Something Happened on the Way to Heaven}

We've mentioned earlier that the "flights" of our curriculum "airplane" were often bumpy and didn't get to the destination as 
Evy I. Siregar et al.

"scheduled". What we mean is that many of our task designs have failed to generate pleasant and productive learning processes or achieve the desired objectives. Yet, failure is an indispensable part of a learning process, and thus should never be avoided (except when we make the same mistakes twice!).

So, what do you do when your plane takes the wrong turn, a.k.a your task design doesn't meet the objectives or worse, doesn't generate any learning, for part of or the whole class? First, don't panic! The learning responsibility and control do not exclusively belong to you. In fact, most part of them belong to your students as the learners. You are not a god, so whatever problems you have, it's better to share them with your students. Who knows? They just might have the solution. Second, do identify the problem. Discuss with your students, why aren't the objectives being met? Or why some students are learning and others don't? or why isn't anybody learning anything? Many factors may contribute to the problem, but it's usually due to the incompatibility of the tasks with the learners and lack of background knowledge on part of the learner. Third, whatever the problem is, improvisations and modifications are no crimes, so do be creative and flexible. As a matter of fact, as you may have realized, being able to think on your feet is one very handy skill for teachers. Fourth, don't hesitate to add or reduce the amounts of tasks and/or time that you have allocated for completion of the tasks. Fifth, if you are the more anticipative type and have much time on your hand, then do prepare plans B, C, D and so on, in case plan A goes down the drain. Lastly, don't ever be discouraged by failures, because each failure is a step ladder to success.

\section{Coming with Us?}

From the two previous examples of task designs, it is confirmed that a well designed curriculum, such as that of Cambridge IGCSE and A Level, indeed provides a solid foundation for effective task designs, which lead to effective students' learning. Yet, curriculum is just a base on which we, the instructional de- 
Think Future, Act Present: Looking Beyond the Closed Door

signers, must develop a conducive environment of learning for our students to fill with their learning constructions. Hence, it is up to us, the teachers, to take advantages from and build on any curriculum a facility for our students' learning. Below are some examples of effective task designs based on different curricula, and the discussion on what things may help in the implementation of task designs in general classrooms.

\section{Mathematics}

Math task design based on Indonesian National Curriculum for Elementary School

Third Grade, Second Semester

\begin{tabular}{|l|c|}
\hline \multicolumn{1}{|c|}{ Standard of Competence } & \multicolumn{1}{c|}{ Basic Competence } \\
\hline 5. $\begin{array}{l}\text { Calculate the perim- } \\
\text { eter and area of square } \\
\text { and using it in problem } \\
\text { solving }\end{array}$ & 5.2 Calculate area of square \\
\hline
\end{tabular}

\section{Guide for teachers on calculating area}

1) Take a piece of square $\square$ (it can be made using hard tick paper, or just draw it)

2) Let's say that each of that form represents area unit 'one'

3) Ask student to count the area of form

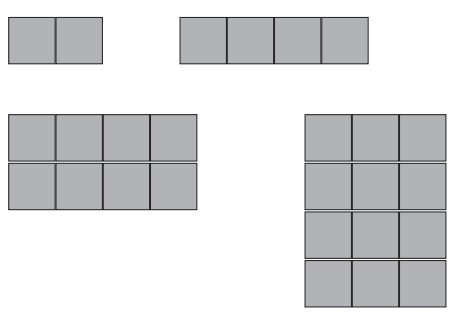

4) Make as many forms of square as possible, and direct student to calculate the area by multiplying the amount of forms in 
Evy I. Siregar et al.

the colomn by the amount of forms in the row.

5) Make different types, such as:
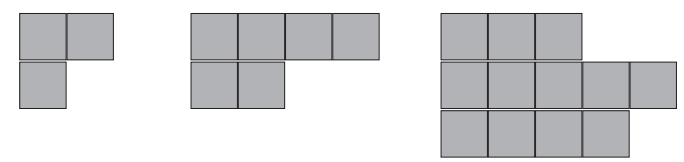

6. And lead student to calculate the area as:
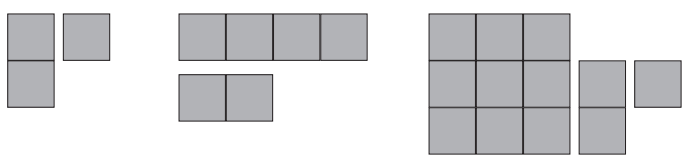

7. Make sure that student understand that if we have an unfamiliar form, we can seperate the squares to produce a more familiar form.

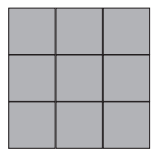

8. Then ask student to make a square of $3 \times 3 \mathrm{~cm}$ in their book, and for each side make a mark (point) for each $1 \mathrm{~cm}$ and connect every two points facing each other.

9. Each square in the above figure represents an area of $1 \mathrm{~cm}^{2}$

10. Ask student to calculate the area of that form.

11. Repeat steps 3-7.

12. Ask studenst to discuss how to calculate the area of a square.

13. Once we're sure that our students understand how to calculate the area of square form, ask them to calculate the area of things in classroom such as white board or area of table surface. 


\section{General English for Children}

This was a class of 11 elementary students aged 10-12. Most of them have high kinesthetic and visual spatial intelligences and auditory learning styles, which means they simply cannot sit still and quietly! The message of the curriculum was that the students should be able to use prepositions of place.

After a review of prepositions of place-in, on, behind, under, in front of, next to, etc-and names of things-scissors, hat, marker, socks, pencil, triangle, rectangle, etc-the students were distributed into 3 groups of 3 and 1 pair. Each group and pair was given a list of things that had been hidden in and outside the classroom. Their first task, then, was to find all of the things in their lists within 15 minutes; the group that completed the task first was the winner, thus earned a reward. While they were trying to find the items in their lists, they must make notes of the detailed locations of the items, e.g. "The red marker was on a table in the classroom," or "The yellow crayons were under a chair in front of the classroom," or "One party hat was next to the computer in the next classroom, and the other one was behind a classroom cabinet," and so on. Once they have finished, they reported their findings to the class, while receiving feedbacks on whether they have used the prepositions of place correctly. Upon receiving the feedbacks, students revise their reports in their group. Before they submit their revised reports, students were given time to memorize the locations of some, if not all, of the items they've found.

After they submit the reports, the students participated in a quiz game, in which they were distributed into 3 new groups, so that each of the new group would be composed of members from all the three previous groups. In the first round, the teacher asked to each group questions such as, "Where did you find the red marker?" Whichever member of the group knows the answer, he or she can raise their hands and give the answer; for example, "It was on a table in the classroom." In the next round, teacher took an item, and put it somewhere in the classroom, then asked 
Evy l. Siregar et al.

questions such as, "The red marker was on a table in the classroom, but where is it now?" Anyone from any group can answer the questions, like, "It is now under a chair in the classroom." As students gave their answers in this quiz, they are also opened for feedbacks, both from teacher and from peer.

The two task designs above may look very different, as they convey two very different messages to two different groups of students. Yet, both still follow the same principles of learner-centered and constructive active learning by allowing ample times for students to experience learning and then come up with their own conclusions of concept, knowledge and skills, as well as to apply and practice the knowledge and skills they have constructed. In keeping to that, the mathematics task design is not merely trying to teach students to calculate an area with a formula, but beyond that, it compels students to come up with a formula of their own. Hence, new scientists are born! Still on the same path, the General English task design attempts to cater for students' multiple intelligences, learning styles and interests, while at the same time, giving them concrete experiences of using prepositions of place in real-life contexts and situations.

You might say that, "Well, those task designs look nice on paper and may work with less than 30 students, but mine got 45 in it!" Well, earlier we have mentioned how students' differences are more of assets than obstacles for learning. The same goes for number of students. Large number of students means more flexible and elaborate activities, which may accommodate more learning, and often means more fun, too! The classic classroom management methods of pairing and grouping are still very much usable, and a component of AfL, self and peer evaluation, is especially helpful in large classes. And nowadays, other than from books, we can find many most helpful resources online to enrich our task designs. Thank God for the Internet!

Other than number of students and their differences, our own classrooms, schools, other teachers, parents, and school sorroundings are also assets that we can use to our students' 
advantage. We can start by our classroom settings; seating arrangements, classroom atmosphere, etc. Furthermore, we can involve other teachers and parents as resource person, guest teacher, or even assisstants. Not only that, if, let's say our school is regularly flooded every year, we could design our tasks around the issue of flood; for example, have the students do a cross-curricular-and, with the help of the Internet, even crossnational-project on flood prevention, or simply write a letter to the Mayor to give him/her some ideas on how to solve the problem.

Finally, designed tasks will, of course, work even better when school policies are aligned with the curriculum goals and assessment objectives. If the curriculum demands students to be independent and active learners, then school policies must be more process, instead of result, oriented. Furthermore, as Puntis and Sismey (2004) put it,

Above all, to develop such skills in students we must empower teachers. Equipping teachers themselves with new skills in which the focus moves away from teaching as the core activity towards a focus on enabling students' learning. 'Managing learning' describes this new skillset very well and in CIE we have designed a number of strategies to support teachers around the world in making this paradigm shift.

So, if the curriculum desires students to master all knowledge and skills as well as having all characters needed to flexibly adapt to future changes and development, then school must first invest on the teachers, the instructional designers, who hold, operate and control the curriculum-messages-delivery device known as task design.

\section{Lesson learned}

As have been mentioned before, experience shows that focusing on content knowledge does not help students become successful learner, for successful learning show evidence of change in attitude, belief as well as in the mastery of knowledge. 
When preparing the whole person through specific interests rather than focusing on academic talent and interests alone, many ways could be adopted which are both effective in leading learners the way to become humans who are independent and creative thinkers through structured and varied activities. Through the various activities learners are educated with norms and values integrated into their learning sessions that those norms and values are assimilated as whole learning experience. In this way, learners created their own belief and attitude with deeper understanding of their values. It become parts of their personality rather than acquired knowledge only.

Aside from the end result of learners, the learning process also creates in learner the awareness that learning is their own responsibility. The success as well as failure of the experience are felt and are theirs alone. What they take from the experience is what is important as the milestone of their learning journey. Yet, these experiences also give them the confidence to face problem in any form, including assessment and test. And in this way they would have the confidence, ability and capability to be measured with any form of measurement and come out a winner.

As for teachers involved in this type of educational process, they would encounter a working environment that is always contributing to their own professional development. The opportunities to share their workload, failure as well as success keep them in the path of life-long learner that is advantageous for them personally. It is an ideal situation for development for any educational institution.

All the above discussion leads us to believe that this process approach with a focus on students' learning will create opportunities for educational institution to contribute in training skillful world citizens with outstanding characters. 


\section{BIBLIOGRAFI}

Black, P \& William, D. 1998. Inside the black box: raising standards through classroom assessment. Nfer Nelson Publishing Company, London: $21 \mathrm{p}$.

Black, P. et al. 2002. Testing, Motivation and Learning. The Assessment Reform Group, Cambridge: i+16

Butler, R. 1988. Enhancing and undermining intrinsic motivation: the effects of task- involving and ego involving evaluation on interest and performance. British Journal of Educational Psychology (58), pp 1-14

Cassidy, N. 2007. English, Effective teaching strategies for Assessment for Learning. CIE $4^{\text {th }}$ International Teachers' Conference, $13^{\text {th }}$ $14^{\text {th }}$ November, 2007, Kuala Lumpur.

CIE (2007) GCE A/AS Level Biology Syllabus, No. 9700, Cambridge: CIE

Mergel, B. 1998. Instructional Design \& Learning Theory, Saskatchewan: 1-27.

Mosley, D et al. 2005. Frameworks for Thinking. A Handbook for Teaching and Learning, Cambridge University Press. Cambridge; UK

Puntis, A \& Sismey, V. 2004. Pre-University Qualifications for International Student Mobility - the Cambridge Perspective. $18^{\text {th }}$ IDP Australian International Education Conference International Education: The path to cultural understanding and development, 5th - 8th October, 2004, Sydney Convention Centre, Sydney: 1-10.

Stith, J.BB. The use of the movie "Lorenzo's Oil” as a Teaching Tool. http://carbon.cudenver.edu/ bstith/loren.htm, 15 Maret 2007.

Yukon Literacy Coalition. 2005. Simple Steps: A workbook to help you plan a Community Literacy Project, Yukon: iii+47 p. 